\title{
Occurrence and risk assessment of parabens and triclosan in surface waters of southern Brazil: a problem of emerging compounds in an emerging country
}

\section{Ocorrência e avaliação de risco de parabenos e triclosan em águas superficiais na região sul do Brasil: um problema de poluentes emergentes em um país emergente}

\author{
Mauricius Marques dos Santos ${ }^{1}$, Franciane de Almeida Brehm ${ }^{1}$, Tais Cristina Filippe ${ }^{1}$, \\ Heloise Garcia Knapik ${ }^{2}$ and Júlio César Rodrigues de Azevedo ${ }^{1}$ \\ ${ }^{1}$ Universidade Tecnológica Federal do Paraná, Curitiba, PR, Brazil \\ ${ }^{2}$ Universidade Federal do Paraná, Curitiba, PR, Brazil \\ E-mails: mauriciusms@gmail.com (MMS),fran_brehm90@hotmail.com (FAB), taisfilippe@gmail.com (TCF), heloise.dhs@ufpr.br (HGK), \\ jcrazevedo@utfpr.edu.br(JCRA)
}

Received: January 30, 2016 - Revised: April 10, 2016 - Accepted: May 03, 2016

\begin{abstract}
Parabens and triclosan compounds are widely used in pharmaceutical products, personal care, food and various products of daily use. After use, the final destinations of these contaminants are domestic effluents and the environment if not collected or treated. The objective of this study was to evaluate the presence of parabens and triclosan in environments in a subtropical region, more specifically in the metropolitan region of Curitiba (southern Brazil) and possible effects of these compounds in aquatic environments through risk assessment through the use of risk quotient (RQ). Samples were collected in 20 points for 4 campaigns. For the extraction of the compounds we used the extraction technique of solid phase extraction (SPE). The determination of the compounds was using gas chromatography coupled to mass spectrometry (GC-MS). It was observed high concentrations of parabens, especially MeP (up to $2875 \mathrm{ng} \mathrm{L}^{-1}$ ). Despite high concentrations of parabens, their presence has a low risk to aquatic organisms. Triclosan has been observed at higher concentrations $\left(415 \mathrm{ng} \mathrm{L}^{-1}\right)$, suggesting once again that these environments are impacted by human action. The RQ assessed that triclosan has a high risk for certain groups of organisms.
\end{abstract}

Keywords: Emerging pollutants; Risk assessment; Triclosan; Parabens; Domestic sewage.

\section{RESUMO}

Parabenos e triclosan são usados amplamente na composição de produtos farmacêuticos, cuidado pessoal, alimentos e diversos produtos de uso cotidiano. Após seu uso, o destino final destes contaminantes são os efluentes domésticos e o meio ambiente, caso não seja coletado ou tratado. A presença destes poluentes emergentes podem apresentar efeitos adversos ao meio ambiente. O objetivo desse estudo foi avaliar a ocorrência de parabenos e triclosan em ambientes de uma região subtropical, mais especificamente na Região Metropolitana de Curitiba (sul do Brasil) e avaliar possíveis efeitos desses compostos em ambientes aquáticos, através da avaliação de risco através do quociente de risco (QR). Foram coletadas amostras em 20 pontos em rios da Região Metropolitana de Curitiba, durante quatro campanhas. Para a extração dos compostos, foi utilizada a técnica de extração em fase sólida (SPE), com determinação por cromatografia gasosa acoplada à espectrometria de massas (GC-MS). Foram observadas elevadas concentrações de parabenos, especialmente $\mathrm{MeP}$ (máximo de $2875 \mathrm{ng} \mathrm{L}^{-1}$ ). Apesar das concentrações elevadas de parabenos a presença dos mesmos apresentou baixo risco para os organismos aquáticos. Quanto ao triclosan, observaram-se também elevadas concentrações $\left(415\right.$ ng $\left.\mathrm{L}^{-1}\right)$, sugerindo mais uma vez que esses ambientes encontram-se impactados pela ação humana. O valor de QR permitiu avaliar que o triclosan apresentou um elevado risco para certos grupos de organismos.

Palavras-chave: Poluentes emergentes; Avaliação de risco; Triclosan; Parabenos; Efluentes domésticos. 


\section{INTRODUCTION}

The continued population growth has led to a corresponding growth on fresh water demand, energy production and other resources. Surface water pollution threatens the aquatic environment with possible acute and chronic effects to organisms. Therefore, protect the integrity of water resources is one of the most critical environmental problems (KOLPIN et al., 2002).

Parabens, alkyl esters of p-hydroxybenzoic acid compounds are widely used as preservatives in pharmaceuticals, personal care products (toothpastes, deodorants, creams, sunscreens, shampoos and bath gels) and food and drink (MEYER et al., 2007; LUNDOV et al., 2009; GONZALEZ-MARINO et al., 2011; ALBERO et al., 2012b; LARSSON et al., 2014; SPANIER et al., 2014). Currently, seven types of parabens (methyl, ethyl, propyl, isopropyl, butyl, isobutyl, and benzyl) are commonly used in these commercially available products (SONI; CARABIN; BURDOCK, 2005; BRAUSCH; RAND, 2011).

In Brazil and in the European Union, the addition of these compounds is limited to a maximum concentration of $0.4 \%$ $(\mathrm{m} / \mathrm{m})$ for a single paraben or $0.8 \%(\mathrm{~m} / \mathrm{m})$ when considering the mixture of more than one type of compound. Although these compounds are readily biodegradable under aerobic conditions, parabens, due their high consumption and continuous input in aquatic environments, can be considered as pseudo persistent (ALBERO et al., 2012a).

Parabens removal rates from sewage treatment plants, especially in aerobic systems, are usually high. Degradation is usually associated with the length of parabens carbon chain. Short chain compounds, such as methylparaben and ethylparaben, can reach up to $99 \%$ degradation at 2.1 days. On the other hand, compounds as propylparaben and butylparaben may take about 3.7 and 4.5 days to reach the same level of degradation (GONZALEZ-MARINO et al., 2011). Gasperi et al. (2014) conducting a study in France, and Albero et al. (2012a), in a study in Spain, indicated that besides degradation may be occurring sorption of parabens in the mud.

Surface water samples quantification can be carried out through solid phase extraction (SPE) (PENG et al., 2008; PEDROUZO et al., 2009; KASPRZYK-HORDERN; DINSDALE; GUWY, 2009; YAMAMOTO et al., 2011; SPONGBERG et al., 2011; RAMASWAMY et al., 2011; AZZOUZ; RASCÓN; BALLESTEROS, 2016).

The analysis of extracted compounds are carried out by chromatographic techniques, such as liquid chromatography (the most commonly used technique) (BENIJTS; LAMBERT; LEENHEER, 2004; BLAIR et al., 2013; KOSMA; LAMBROPOULOU; ALBANIS, 2014) or gas chromatography (LEE; PEART; SVOBODA, 2005; RAMASWAMY et al., 2011; ALBERO et al., 2012b; AZZOUZ; RASCÓN; BALLESTEROS, 2016).

Due to its high consumption, parabens have been found in various surface water matrices (BENIJTS; LAMBERT; LEENHEER, 2004; JONKERS et al., 2009; VILLAVERDE-DE-SÁA et al., 2010; GORGA; PETROVIC; BARCELO, 2013), air and dust samples (CANOSA et al., 2006), soil (FERREIRA; MÖDER; LAESPADA, 2011) and on sewage sludge (LEE; PEART; SVOBODA, 2005; ALBERO et al., 2012a; GASPERI et al., 2014).

Another compound found in personal care products is triclosan (5-chloro-2- (2,4-dichlorophenoxy) -phenol) molecule with bactericides and antimicrobial properties (OKUMURA; NISHIKAWA, 1996; SCHWEIZER, 2001; MCAVOY et al., 2002; SINGER et al., 2002; CANOSA et al., 2006; CHAU; WU; CAI, 2008). Triclosan is also known as its endocrine interference properties (ROUTLEDGE et al., 1998; BYFORD et al., 2002; SONI; CARABIN; BURDOCK, 2005; BOBERG et al., 2010).

Triclosan has been found in aquatic environments in different parts of the world (BENIJTS; LAMBERT; LEENHEER, 2004; HALDEN; PAULL, 2005; KASPRZYK-HORDERN; DINSDALE; GUWY, 2009; VILLAVERDE-DE-SÁA et al., 2010), in wastewater, seawater, soil, and sediments (LOPEZAVILA; HITES, 1980; OKUMURA; NISHIKAWA, 1996; LINDSTROM et al., 2002; MCAVOY et al., 2002; SINGER et al., 2002; CHAU; WU; CAI, 2008).

One of the concerns of the presence of triclosan in aquatic environments may be related to its potential effect on some classes of organisms such as algae. The high sensitivity of algae to triclosan is likely related to its antibacterial characteristics that may affect various mechanisms, such as lipid synthesis (LU; ARCHER; 2005; FRANZ et al., 2008), stabilization of cell membrane or uncoupling phosphorylation (NEWTON et al., 2005) since these mechanisms are very similar to bacteria and algae (COOGAN et al., 2007; BRAUSCH; RAND, 2011).

Another possible effect of triclosan in the aquatic environment that can affect human health is through the formation of resistant organisms to antimicrobial agents and antibiotics (BRAUSCH; RAND, 2011).

In such context, one way to evaluate possible effects is the use of risk quotients (RQ). The use of RQ takes into account the environmental measured concentration and the concentration at which the compounds are toxic to certain organisms (RAMASWAMY et al., 2011; YAMAMOTO et al., 2011; BLAIR et al., 2013). However, one of the greatest challenges in the calculation of RQ is the lack of information regarding the toxicity of the compounds (BLAIR et al., 2013).

Environments with low, medium or high risk of exposure to different emerging pollutants and for different trophic levels have been classified through RQ data (CHRISTENSEN et al., 2009; VALCARCEL et al., 2011; Al-AUKIDY et al., 2012; VERLICCHI; AL AUKIDY; ZAMBELLO, 2012; BLAIR et al., 2013; TEWARI et al., 2013; YU; WU; CHANG, 2013).

Thus, this study aims in determining the presence of parabens and triclosan in aquatic environments at Curitiba region (southern Brazil) and to study possible effects of these compounds using risk quotients (RQ).

\section{METHODOLOGY}

\section{Study area}

The study area is located in the subtropical region of Brazil, at the Upper Iguassu Watershed, Metropolitan Region of Curitiba (RMC). This watershed contributes to $60 \%$ of the water supply sources for RMC. However, the uncontrolled anthropogenic occupation and the elevated rates of illegal connections in the domestic wastewater system also contributes to the release of high 
amounts of sewage into the aquatic ecosystems (ANDREOLI et al., 1999).

The presence of domestic effluents at RMC rivers can be confirmed by the measurement of emerging contaminants. Ide et al. (2013) quantified caffeine in some rivers of the RMC, while Kramer et al. (2015) quantifyed diclofenac (DIC), ibuprofen (IBU), and paracetamol (PAR). Osawa et al. (2015) quantified antihypertensive compounds, confirming the presence of domestic effluents at RMC rivers.

Currently, RMC includes 13 cities located around the city of Curitiba, with a population of approximately 3 million people, accounting for about $25 \%$ of Paraná State population.

The Upper Iguassu Watershed has a total area of approximately $2882 \mathrm{~km}^{2}$. Some of the major rivers were considered for the monitoring strategy of the present study: Iguassu (main river), Atuba, Irai, Rio Barigui, Palmital, Belém and Pequeno Rivers (Figure 1). Considering the Iguassu Watershed, the main river, Iguassu River, has a total length of $910 \mathrm{~km}$, and of these, approximately $100 \mathrm{~km}$ in the MRC (Upper Iguassu Watershed).

Surface water samples were collected in rivers of the Metropolitan Region of Curitiba, close to its headwaters (Pequeno River - PQ1, Palmital River - PA1, and Atuba River - AT1), resulting in a total of 20 sites at Upper Iguassu Watershed. Samples were collected in September/2011 November/2011, April/2012, and
June/2012. Samples were collected in glass amber decontaminated bottles and stored at $4{ }^{\circ} \mathrm{C}$ until analysis. Decontamination of amber vials was initially performed with $5 \% \mathrm{HCl} \mathrm{v/v} \mathrm{solution.}$ Subsequently, all vials were rinsed and left to Extran detergent solution $5 \% \mathrm{v} / \mathrm{v}$. Glass amber bottles were placed in a muffle furnace and heated to $450{ }^{\circ} \mathrm{C}$.

Atuba, Belém, Palmital and Barigui Rivers are polluted as a consequence of its high population density and irregular occupation on its drainage area, with illegal connections and releases of domestic effluents and solid waste. Atuba River (AT4) and the Barigui River (BA2) receive the effluent of an anaerobic domestic sewage treatment plant. Barigui watershed is also characterized by the presence of a large number and diversity of industries. Palmital river has lower demographic influence, but also presents problems of collection and treatment of domestic sewage toward your drainage area.

$\mathrm{N}$-ammonia, chloride, sulfate, nitrate, nitrite, orthophosphate, and total phosphorus were determined by methodologies described in Standard Methods for the Examination of Water and Wastewater (APHA, 1998). $\mathrm{pH}$, temperature, dissolved oxygen (DO), redox potential (ORP), conductivity and salinity were measured by a multiparameter probe (Hanna). Dissolved organic carbon (DOC) was analyzed by the combustion of organic matter (Thermo Electron Corporation - HiperTOC).

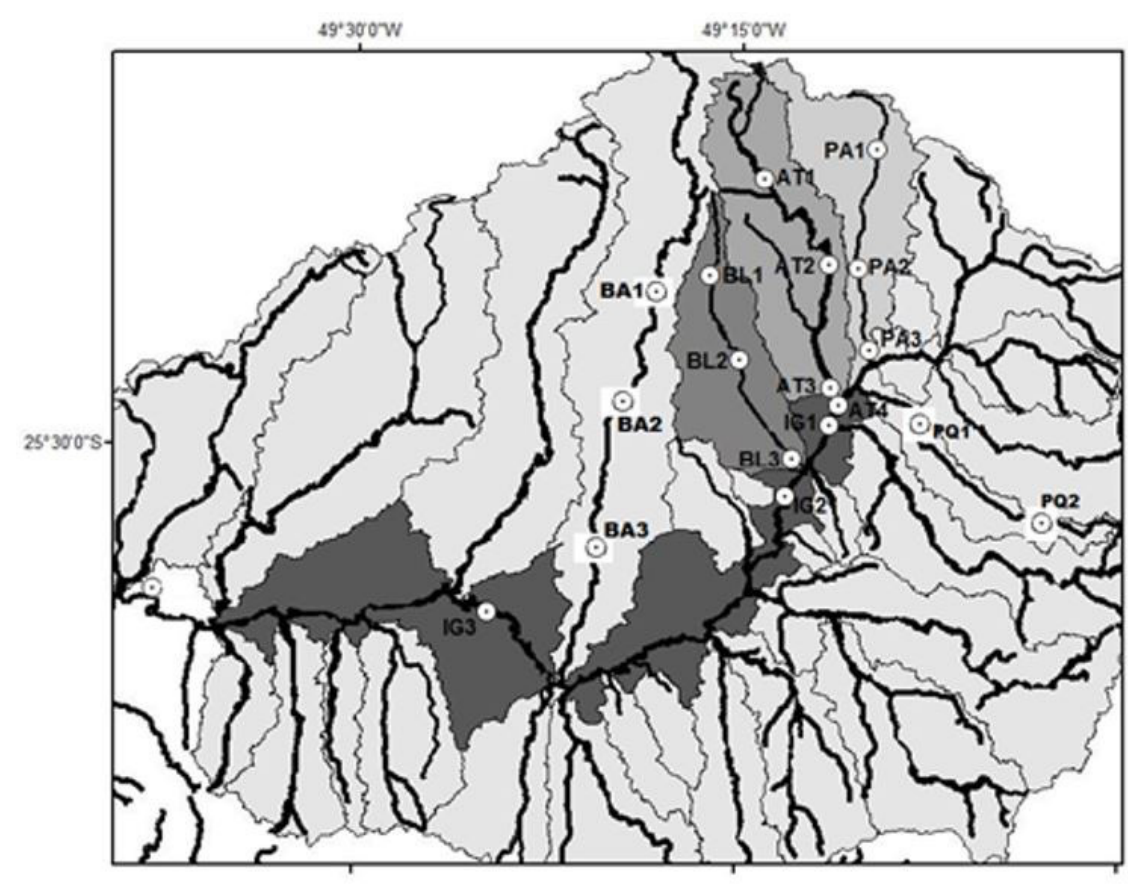

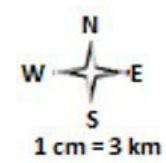

Projection Universal Transverse Mercator South America Datun 1969 Zone: $22 \mathrm{~S}$

\author{
Legends \\ $\odot$ Sampling sites \\ River
}

Palmital River (PA)

Atuba River (AT)

Pequeno River (PQ)

Belém River (BL)

Barigui River (BA)

Iguassu River (IG)

Upper Iguassu Watershed
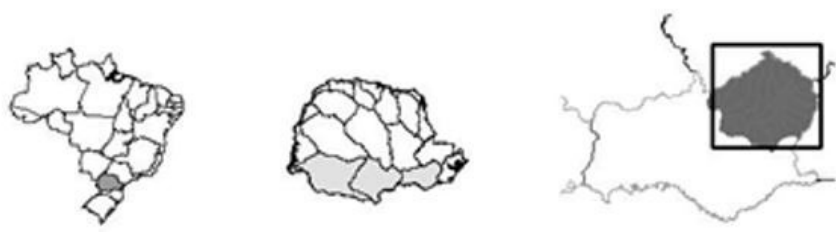

Figure 1. Study area and sampling sites at Upper Iguassu Watershed (Curitiba and Metropolitan Region): Iguassu (IG), Palmital (PA), Iraí (IR), Atuba (AT), Pequeno (PQ), Belém (BL), and Barigui (BA) rivers. 


\section{Extraction and determination}

Methylparaben (MeP), ethylparaben (EtP), propylparaben (PrP), butylparaben (BuP), benzylparaben (BzP), triclosan (TCS) and (N, O-bis (trimethylsilyl) trifluoacetamida / 1\% trimethylchlorosilane (BSTFA / 1\% TMCS) were from Sigma-Aldrich. Ethyl acetate and HPLC-UV grade methanol were from J. T Baker and Tedia. Cartridges C18 Bond Elute 1000mg 6mL were from Agilent Technologies.

Extraction procedures were based on Ramaswamy et al. (2011). For compound extraction, samples were filtered through a $0.45 \mu \mathrm{m}$ acetate cellulose membrane and the $\mathrm{pH}$ were adjusted to 7. Extraction C18 cartridges were conditioned with $6 \mathrm{~mL}$ of ethyl acetate, $6 \mathrm{ml}$ of methanol and $6 \mathrm{ml}$ of water. One liter of the sample were passed through the cartridge at a flow rate of $5-7 \mathrm{ml} \mathrm{min}^{-1}$. Cartridges were then dried in nitrogen flow and 4 fractions eluted with $4 \mathrm{ml}$ of a mixture of ethyl acetate: methanol $(1: 1) \mathrm{v} / \mathrm{v}$. The extracts were transferred to reaction vials and then taken to dryness. Determination was performed after derivatization with $50 \mathrm{uL}$ of BSTFA / TMCS $1 \%$ at $70{ }^{\circ} \mathrm{C}$ for one hour. Samples were reconstituted to a final volume of $1 \mathrm{~mL}$ of ethyl acetate.

For parabens and triclosan determination, a gas chromatograph coupled to a mass spectrometer ion trap type (MS-210 GC431 IT - Varian, Inc.) has been used. A capillary chromatographic column VF-5MS type $(30 \mathrm{~m} \times 0.25 \mathrm{~mm} \times 0: 25 \mathrm{uM})$ was used. A flow rate of $1.0 \mathrm{~mL}$ per minute of helium 6.0 as a carrier gas was used. The injection of $1 \mathrm{uL}$ was performed in in the splitless mode and the injector temperature was maintained at $280^{\circ} \mathrm{C}$. The initial furnace temperature was $70^{\circ} \mathrm{C}$ for one minute, then raised to $100{ }^{\circ} \mathrm{C}$ at a rate of $30{ }^{\circ} \mathrm{C} \mathrm{min}^{-1}$ and then raised $240{ }^{\circ} \mathrm{C}$ at a rate of $5^{\circ} \mathrm{C}$ per minute. Finally, the temperature was raised to $300{ }^{\circ} \mathrm{C}$ at a rate of $30^{\circ} \mathrm{C} \mathrm{min}^{-1}$ and remained at that temperature for 5 minutes. The filament delay was set to 12 minutes and the acquisition range set in $50-650 \mathrm{~m} / \mathrm{z}$. The temperature of the ion trap was set at $200{ }^{\circ} \mathrm{C}$, the transfer line at $280^{\circ} \mathrm{C}$ and maninfold at $60{ }^{\circ} \mathrm{C}$. Retention times and ions used in quantitation and identification of the compounds are shown in Table 1.

Method validation was performed through recovery tests two different concentrations $(\mathrm{N}=5$ ). To assess possible contamination, white samples were conducted during the analysis. Tests were also conducted to verify the repeatability using 5 injections on the same day $\left(2 \mathrm{ng} \mathrm{L^{-1 }}\right)$. For reproducibility of the method, a sample at $2 \mathrm{ng} \mathrm{L^{-1 }}$ was injected 5 times a day for 3 consecutive days $(\mathrm{N}=15)$.

\section{Risk assessment}

For the risk assessment were used concentration values without effect (Predicted No Effect Concentration - PNEC), based on the EC50 values (concentration that induces half the maximum effect) or LD50 (median lethal dose) for acute toxicity tests for different organisms found in the literature (CHRISTENSEN et al., 2009; VALCARCEL et al., 2011; AL-AUKIDY et al., 2012; VERLICCHI; AL AUKIDY; ZAMBELLO, 2012; BLAIR et al., 2013; TEWARI et al., 2013; YU; WU; CHANG, 2013).

RQ values were calculated for acute tests for $P$. subcapitata considering parabens and D. tertiolecta (algae), Vibrio fisheri (bacteria) to Daphinia magna (microcrustacean) and Pimephales minnows (fish).

For chronic toxicity tests were used NOEC values (No Observed Effect Concentration). For the determination of acute PNEC and chronic PNEC, EC50 values (or LC50) and NOEC were divided by an assessment factor (AF). For acute tests it was adopted an AF 100, and for chronic tests an AF 10 (YAMAMOTO et al., 2011).

In the risk assessment, values greater than 1 indicate environmentally relevant concentrations and a high risk to organisms, while values between 1 and 0.1 suggest a medium or moderate risk. Values below 0.1 indicate a low risk to organisms considering analyzed compounds (YAMAMOTO et al., 2011).

In order to reduce data dimensionality and observe sites and/or monitoring periods group formation, a Principal Component Analysis was performed. For this analysis, values obtained from the monitoring were previously processed $[\log (x+1)]$, except $\mathrm{pH}$, in order to remove the effects caused by the data variation. A Pearson correlation analysis has also been applied to the parameters analyzed.

\section{RESULTS AND DISCUSSION}

\section{Validation and quality control}

A summary of obtained data from the validation step can be seen in Table 1. For white samples performed during validation tests, no signs of the compounds analyzed in this study were observed. The recoveries for both levels tested were greater than $90 \%$, indicating a good compound recovery for the proposed method. The correlation coefficient $\left(\mathrm{R}^{2}\right)$ for all the examined compounds was higher than 0.99. Parabens and triclosan limits

Table 1. Instrumental parameters of chromatographic validation and extraction method of the analyzed compounds: MeP (methylparaben), EtP (ethylparaben), PrP (propylparaben), BuP (butyilparaben) and BzP (benzylparaben) and triclosan (TCS).

\begin{tabular}{|c|c|c|c|c|c|c|c|c|c|}
\hline & \multirow{2}{*}{$\begin{array}{c}\mathbf{T R}^{\mathrm{a}} \\
(\mathrm{min})\end{array}$} & \multirow{2}{*}{$\begin{array}{l}\text { Mass } \\
(\mathrm{m} / \mathrm{z})\end{array}$} & \multirow[b]{2}{*}{$\mathbf{R}^{2}$} & \multirow[b]{2}{*}{$\mathrm{LOD}^{\mathrm{b}}$} & \multirow[b]{2}{*}{$\mathrm{LOQ}^{\mathrm{c}}$} & \multicolumn{2}{|c|}{ Recovery } & \multirow{2}{*}{ 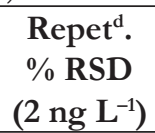 } & \multirow{2}{*}{$\begin{array}{l}\text { Reprod }^{\mathrm{e}} \text {. } \\
\% \text { - RSD } \\
\left(2 \mathrm{ng} \mathrm{L}^{-1}\right)\end{array}$} \\
\hline & & & & & & $2 \mathrm{ng} \mathrm{L}^{-1}$ & $20 \mathrm{ng} \mathrm{L}^{-1}$ & & \\
\hline $\mathrm{MeP}$ & 13.21 & 192-208 & 0.9989 & 1.7 & 5.3 & $93.3 \pm 2.7$ & $98.6 \pm 1.4$ & 3.5 & 4.6 \\
\hline EtP & 14.83 & $192-222$ & 0.9924 & 1.4 & 4.4 & $94.3 \pm 3.5$ & $97.0 \pm 2.9$ & 3.2 & 5.2 \\
\hline PrP & 17.04 & 192-194 & 0.9990 & 1.7 & 5.1 & $92.2 \pm 3.3$ & $95.9 \pm 1.3$ & 3.8 & 5.4 \\
\hline BuP & 19.20 & 192-209 & 0.9989 & 2.0 & 6.1 & $91.8 \pm 1.6$ & $94.8 \pm 3.2$ & 3.6 & 5.6 \\
\hline $\mathrm{Bz} \mathbf{P}$ & 27.09 & 91-192 & 0.9987 & 1.9 & 5.7 & $92.4 \pm 3.0$ & $94.6 \pm 2.7$ & 4.1 & 5.9 \\
\hline TCS & 26.17 & 289-345 & 0.9942 & 0.4 & 1.3 & $94.1 \pm 3.4$ & $98.8 \pm 2.7$ & 3.4 & 5.3 \\
\hline
\end{tabular}


of detection (LOD) were between 0.4 to $2.0 \mathrm{ng} \mathrm{\textrm {L } ^ { - 1 }}$. Established quantification (LOQ) was 1.3 to $6.1 \mathrm{ng} \mathrm{L^{-1 }}$. For both tests on repeatability (precision on the same day) and reproducibility (interday precision) the relative standard deviations ( $\%$ RSD) were less than $10 \%$ for all compounds.

The values found for parabens until $2875 \mathrm{ng} \mathrm{L^{-1 }}$ of $\mathrm{MeP}$ obtained in this study suggest higher concentrations when comparing with other studies (Table 2). Comparable values from MeP were only observed by Peng et al. (2008) in a study conducted in China's rivers with $1062 \mathrm{ng} \mathrm{L}^{-1}$ for $\mathrm{MeP}$ and $2142 \mathrm{ng} \mathrm{\textrm {L } ^ { - 1 }}$ for BuP.

Evaluation of compounds occurrence such as triclosan and parabens in water environments in the world are still limited to only a few studies on a reduced number of countries (Tables 2 and 3). Among the available studies, it as possible to observe a predominance of studies conducted in developed countries, especially those carried out in Spain (KANTIANI et al., 2008; REGUEIRO et al., 2009; MONTES et al., 2009; VILLAVERDE-DE-SÁA et al., 2010; GORGA; PETROVIC; BARCELO, 2013). Complementarily, there was a trend of the highest concentrations of these compounds found in water samples in developing countries such as China (PENG et al., 2008), India (RAMASWAMY et al., 2011) and Brazil (this study). This may be associated with the non-appropriate wastewater collection and treatment rates in developing countries.

Benzylparaben (BzP) concentrations has not being detected in any of the samples. BzP is a paraben with little usage in cosmetics industry. In other studies, BzP has not being detected or quantified at very low concentrations when compared to other types of parabens. BzP concentrations in previous studies in Switzerland samples had concentrations of $4.4 \mathrm{ng} \mathrm{L^{-1 }}$ (JONKERS et al., 2009) at $1.1 \mathrm{ng} \mathrm{L^{-1 }}$ on samples in Spain (GORGA; PETROVIC; BARCELO, 2013).

Worldwide, the largest observed triclosan concentrations are in the order of thousands of $\mathrm{ng} \mathrm{L}^{-1}$. Some values observed in this range of concentration were found in United States - $2200 \mathrm{ng} \mathrm{L}^{-1}$ (KOLPIN et al., 2002). In India, a concentration of $5160 \mathrm{ng} \mathrm{\textrm {L } ^ { - 1 }}$ was observed (RAMASWAMY et al., 2011) and a concentration $1329 \mathrm{ng} \mathrm{L}^{-1}$ in China (ZHAO et al., 2013). In this study, the concentration ranged from below the limit of detection $(<\mathrm{LOD})$ of the method used up to $415 \mathrm{ng} \mathrm{L}^{-1}$ (June 2012) in Rio Barigui.

\section{Spatial distribution and sazonality}

The higher detection frequency for $\mathrm{MeP}(74 \%)$ and $\mathrm{PrP}$ (54\%) (Figure 2) at RMC may be related to the fact that such compounds are the most commonly parabens used in cosmetics, especially in combination, increasing their preservative effect (PECK, 2006; BRAUSCH; RAND, 2011). Figure 3 shows the concentrations of parabens observed in four sample campaigns.

For MeP, it has being observed concentrations up to $2875 \mathrm{ng} \mathrm{L}^{-1}$ in November 2011 at Irai River (IR1), an watershed also impacted by urbanization. Generally, it has being observed higher concentrations for MeP during the first field campaign performed in September 2011. During the other field campaigns,

Table 2. Summary of studies considering triclosan concentration variation analyzed in wastewater and surface water in different countries.

\begin{tabular}{|c|c|c|c|c|}
\hline \multicolumn{2}{|c|}{ Triclosan $\left(n g \mathrm{~L}^{-1}\right)$} & \multirow{2}{*}{ Location } & \multirow{2}{*}{ Country } & \multirow{2}{*}{ Reference } \\
\hline Min & Max & & & \\
\hline- & near 20 & Aabach Mönchaltorf river & Switzerland & Singer et al. (2002) \\
\hline$>0.4$ & 14 & Lakes, rivers and domestic effluents & Switzerland & Lindstrom et al. (2002) \\
\hline 19 & 80 & Aire River Watershed & United Kingdom & Sabaliunas et al. (2003) \\
\hline 30 & 90 & Itter river & Germany & Wind et al. (2004) \\
\hline$\sim 140$ & 2200 & 139 different aquatic environment & USA & Kolpin et al. (2002) \\
\hline- & 107 & Industrial and domestic effluents & Belgium & Benijts, Lambert and Leenheer (2004) \\
\hline$>3$ & 10 & Ruhr river & Germany & Bester (2005) \\
\hline 4 & 8 & Detroit river & Canada & Hua, Bennett and Letcher (2005) \\
\hline 8.8 & 34.9 & Mississippi river & USA & Zhang et al. (2007) \\
\hline$>2$ & 4 & Lake Maggiore & Italy & Loos et al. (2007) \\
\hline$>3$ & 75 & Queensland aquatic environments & Australia & Ying and Kookana (2007) \\
\hline 15 & 110 & Hong Kong aquatic environments & China & Wu et al. (2007) \\
\hline 0.001 & 6.87 & German Bight aquatic environments & Germany & Xie et al. (2008) \\
\hline- & 285 & Northeast of Spain aquatic environments & Spain & Kantiani et al. (2008) \\
\hline 2.5 & 117 & Nu Tung and Lam Tsuen rivers & China & Chau, Wu and Cai (2008) \\
\hline 1 & 9 & Hudson River Estuary & USA & Wilson et al. (2009) \\
\hline 4.9 & 13.7 & Charleston and Indian rivers & USA & Fair et al. (2009) \\
\hline 26 & 105 & Rivers and effluents & Spain & Montes et al. (2009) \\
\hline$>5$ & 24 & Ely and Taff rivers & UK & $\begin{array}{l}\text { Kasprzyk-Hordern, Dinsdale and } \\
\text { Guwy (2009) }\end{array}$ \\
\hline 58 & 138 & Rivers and domestic effluents & Spain & Villaverde-de-Sáa et al. (2010) \\
\hline$\sim 10$ & 5160 & Tamiraparani, Kaveri and Vellar rivers & India & Ramaswamy et al. (2011) \\
\hline$>11$ & 263 & Nation wide & Costa Rica & Spongberg et al. (2011) \\
\hline$>0.5$ & 8 & Greenwich Bay & USA & Katz et al. (2013) \\
\hline- & 2 & Ebro River Watershed & Spain & Gorga, Petrovic and Barcelo (2013) \\
\hline- & 1329 & Liao, Hai, Yellow and Dongjiang rivers & China & Zhao et al. (2013) \\
\hline$<\mathrm{LOD}$ & 415 & Upper Iguassu Watershed & Brazil & This study \\
\hline
\end{tabular}


Table 3. Summary of studies considering parabens concentration variation (ng $\mathrm{L}^{-1}$ ) from surface water sampled in different countries: MeP (methylparaben), EtP (ethylparaben), PrP (propylparaben), BuP (butyilparaben) and BzP (benzylparaben).

\begin{tabular}{|c|c|c|c|c|c|c|c|c|c|c|c|}
\hline \multicolumn{2}{|c|}{ MeP } & \multicolumn{2}{|c|}{ EtP } & \multicolumn{2}{|c|}{ PrP } & \multicolumn{2}{|c|}{ BuP } & \multicolumn{2}{|c|}{$\mathrm{BzP}$} & \multirow{2}{*}{ Country } & \multirow{2}{*}{ Reference } \\
\hline Min & Max & Min & Max & Min & Max & Min & Max & Min & Max & & \\
\hline- & 85.1 & - & 53.8 & - & 78.1 & - & - & - & - & Belgium & $\begin{array}{l}\text { Benijts, Lambert and Leenheer } \\
(2004)\end{array}$ \\
\hline 10 & 48 & 4 & 8 & - & - & - & - & - & - & $\begin{array}{l}\text { United } \\
\text { Kingdom }\end{array}$ & $\begin{array}{l}\text { Kasprzyk-Hordern, Dinsdale and } \\
\text { Guwy (2009) }\end{array}$ \\
\hline- & 1062 & - & - & - & - & - & 2142 & - & - & China & Peng et al. (2008) \\
\hline - & - & - & - & - & 23.8 & - & 54.1 & - & - & Spain & Regueiro et al. (2009) \\
\hline$<0.3$ & 305 & $<0.5$ & 15 & $<0.2$ & 22 & $<0.3$ & 16 & - & - & $\begin{array}{l}\text { United } \\
\text { Kingdom }\end{array}$ & $\begin{array}{l}\text { Kasprzyk-Hordern, Dinsdale and } \\
\text { Guwy (2009) }\end{array}$ \\
\hline 3.1 & 17 & $\sim 0.3$ & 1.6 & $\sim 0.5$ & 5.8 & $\sim 0.2$ & 2.8 & $\sim 0.2$ & 4.4 & Switzerland & Jonkers et al. (2009) \\
\hline- & 54 & 29 & 57 & 0 & 105 & - & 6.4 & - & 2.4 & Spain & Villaverde-de-Sáa et al. (2010) \\
\hline- & 22.8 & 2.47 & 142 & - & 57 & - & - & - & - & India & Ramaswamy et al. (2011) \\
\hline 25 & 676 & $\sim 1.3$ & 64 & $\sim 0.8$ & 207 & $\sim 0.6$ & 163 & $\sim 0.2$ & 2.1 & Japan & Yamamoto et al. (2011) \\
\hline 1.4 & 7.7 & - & 13 & 0.68 & 15 & - & - & - & 1.1 & Spain & $\begin{array}{l}\text { Gorga, Petrovic and Barcelo } \\
\text { (2013) }\end{array}$ \\
\hline$<$ LOD & 2875 & $<$ LOD & 1485 & $<$ LOD & 486 & $<$ LOD & 286 & $<$ LOD & - & Brazil & This study \\
\hline
\end{tabular}

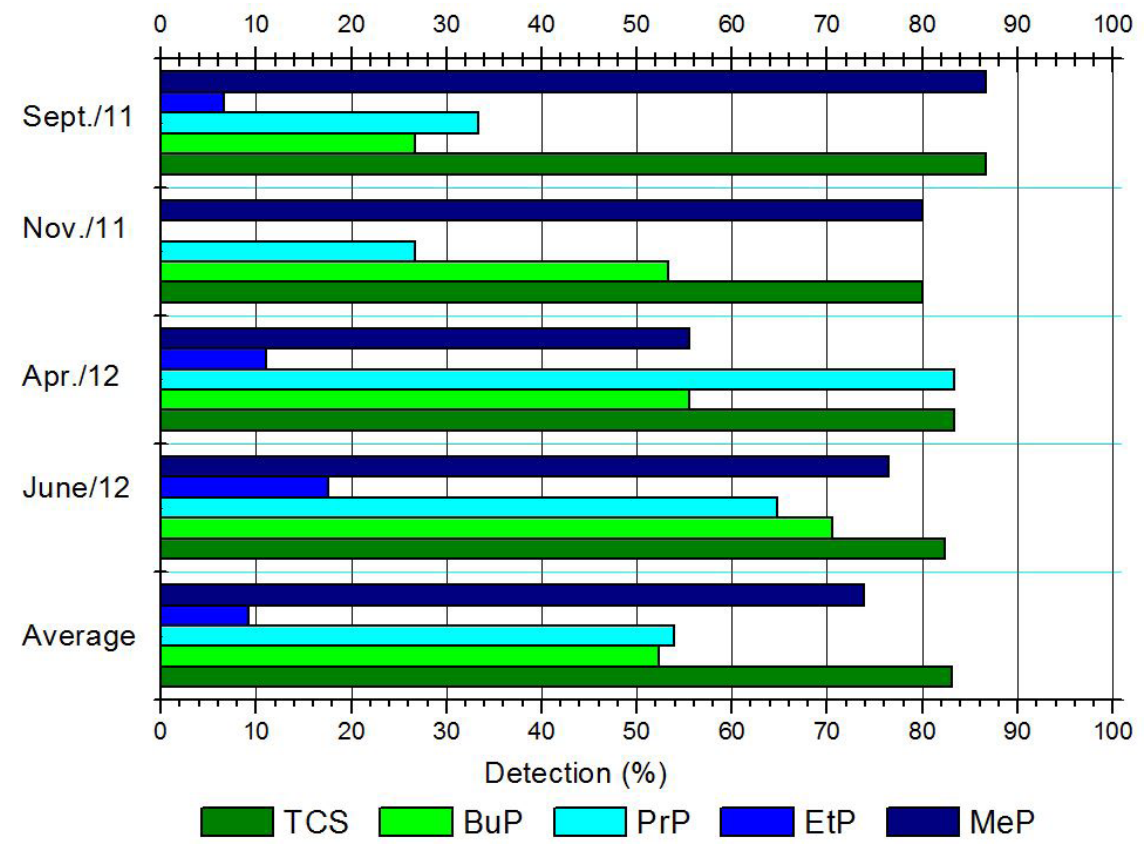

Figure 2. Parabens detection percentage (MeP - methylparaben, EtP - ethylparaben, PrP - propylparaben, BuP - butylparaben) and triclosan (TCS). Sampling performed in Sep/11, Nov/11, Apr/12 and June/12 at Upper Iguassu Watershed.

trends were observed according to the season. In this case, it was not possible to observe patterns in parabens and triclosan concentrations over the months, indicating that consumption and the release of these compounds was intermitent.

EtP paraben has being the second compound less frequently found (less than $10 \%$ of the samples). The low percentage of detection suggests a lower use of this compound in the formulation of the product or due to their degradation. High concentrations of this compound were found in a sample performed at AT4 site in September 2011, with a concentration of $1485 \mathrm{ng} \mathrm{L}^{-1}$. This site is located downstream a sewage treatment plant. Probably, this high concentration found may be related to the low hydraulic detention time (HDT) used in the sewage treatment plant (WWTP). According Gonzalez-Marino et al. (2011), EtP paraben is degraded with longer periods of HDT, being observed about $99 \%$ of degradation in 2.1 days. For the currently WWTP, HDT 

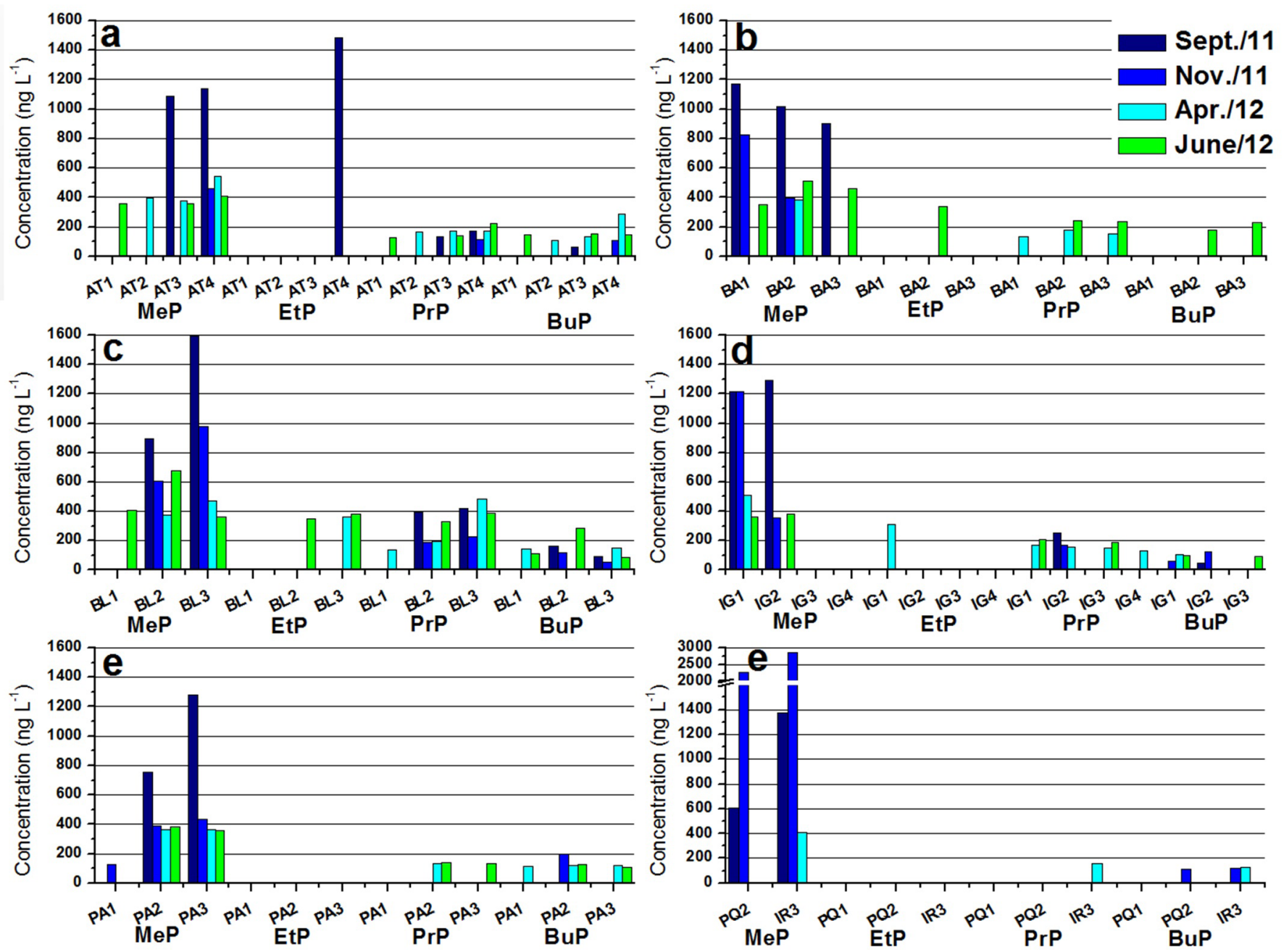

Figure 3. Parabens concentration (MeP - methylparaben, EtP - ethylparaben, PrP - propylparaben, BuT - butylparaben) determined in Palmital (PA), Atuba (AT), Iguassu (IG), Barigui (BA), Belém (BL), Irai (IR) and Pequeno (PQ) rivers. Sampling performed in Sept/11, Nov/11, Apr/12 and June/12 at Upper Iguassu Watershed, metropolitan region of Curitiba.

is about 17 hours. Another aspect that may also be contributing is that it is a highly urbanized area with high rates of untreated domestic effluent releases.

In the other monitored points, concentration variations were observed in the range of $310-381 \mathrm{ng} \mathrm{L}^{-1}$. EtP concentration showed correlated with triclosan $(\mathrm{R}=0.5052, \mathrm{p}<0.001)$ and total phosphorus $(\mathrm{R}=0.5865, \mathrm{p}<0.001)$. These correlations can be an indication that the EtB probably came from the domestic effluents sources.

BuP maximum observed concentration was $286 \mathrm{ng} \mathrm{L}^{-1}$ at Belém River in June 2012. Concentrations above $100 \mathrm{ng} \mathrm{L}^{-1}$ were observed by Yamamoto et al. (2011), which quantified $163 \mathrm{ng} \mathrm{L}^{-1}$ in Japan and Peng et al. (2008), which quantified an amount of $2142 \mathrm{ng} \mathrm{L}^{-1}$ in China. However, $\operatorname{PrP}$ was observed in values of up to $486 \mathrm{ng} \mathrm{L}^{-1}$ in a distinct site located at Belém River in April 2012.

Thus, the presence of parabens in concentrations much higher than those found in other studies, can be explained by the high rate of urbanization in the study area, with a large number of irregular occupations causing direct sewage disposal in nature in many of the analyzed environments.
Domestic wastewater treatment plants can remove and/or degrade up to $90 \%$ for existing parabens in domestic effluents (GONZALEZ-MARINO et al., 2011). Countries where domestic effluents collection and treatment rates are high, compounds such as parabens are not usually found in aquatic environments.

For triclosan, some studies describe lower removal efficiency in sewage treatment plants (SABALIUNAS et al., 2003; MORRALL et al., 2004; HEIDLER; HALDEN, 2007), resulting in similar observed concentrations in environments impacted by untreated domestic effluents and in places that receive treated sewage. The high triclosan concentrations in the environment such as those found in some rivers of India, may be related to the disposal of industrial effluents, especially for textile industry, in which triclosan is commonly used as an antimicrobial agent (RAMASWAMY et al., 2011). In Figure 4 it is possible to observe the triclosan concentration variation in the rivers of the RMC, from detection limit to $415 \mathrm{ng} \mathrm{\textrm {L } ^ { - 1 }}$.

High observed concentrations of parabens and triclosan, which are specifically human originated compounds, can be a result of: 
a) Curitiba presents a collection rate of $91 \%$, but only $65 \%$ of treatment;

b) Part of the collected sewage is discharged directly into the environment without any treatment (through bypass);

c) Irregular occupations may cause a great state of degradation of aquatic environments due illegal connections of sewers connections directly into storm drainage systems and/or rivers;

d) Inefficient removal of parabens and triclosan at sewage treatment plants.

Thus, even compounds that present easy degradation on sewage treatment plants, may not being removed and consequently directly discharged into the rivers. The fact MeP and TCS have not being detected at headwater sites, confirm that the main source of these compounds are domestic sewage.

Comparable concentrations of parabens were only found in a study conducted by Peng et al. (2008) in Perl River in China.
This river is located in a highly populated area, with a population of about 12 million inhabitants and about $30 \%$ of the sewage is discharged directly into the river without any treatment.

Parabens and triclosan concentration distribution under studied environment indicate higher concentrations in environments with increased urbanization. In addition, higher concentration were obtained at sites located downstream of sewage treatment plants, mainly at Atuba (AT4) and Barigui (BA3) rivers, suggesting an inability of removal of these compounds during the treatment process.

Wastewater inputs into rivers can also be demonstrated by the correlation between triclosan and orthophosphate $(\mathrm{R}=0.7753$, $\mathrm{p}<0.001)$, ammonia- $\mathrm{N}(\mathrm{R}=0.4860, \mathrm{p}<0.001)$ and dissolved organic carbon $(\mathrm{R}=0.5907, \mathrm{p}<0.001)$.

Atuba (AT4) and Barigui (BA2) rivers sampling sites, located downstream of sewage treatment plants, showed the highest triclosan values.

Principal component analysis (Figure 5) explained 50.95\% of data total variability. At Belém and Atuba rivers, the most impacted

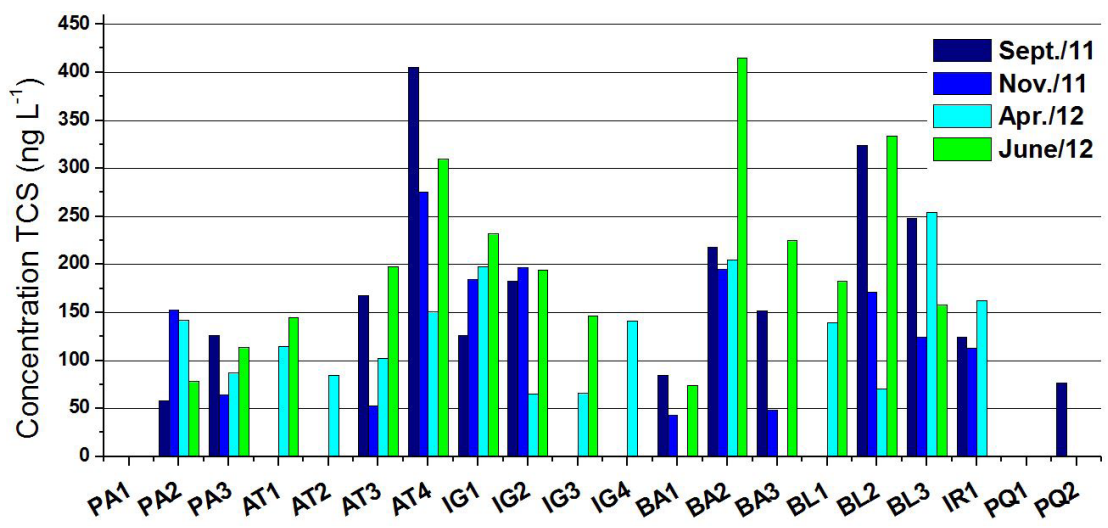

Figure 4. Triclosan concentrations (ng L ${ }^{-1}$ ) determined in Palmital (PA), Atuba (AT), Iguassu (IG), Barigui (BA), Belém (BL), Irai (IR) and Pequeno (PQ) rivers. Sampling performed in Sept/11, Nov/11, Apr/12 and June/12 at Upper Iguassu Watershed, metropolitan region of Curitiba.
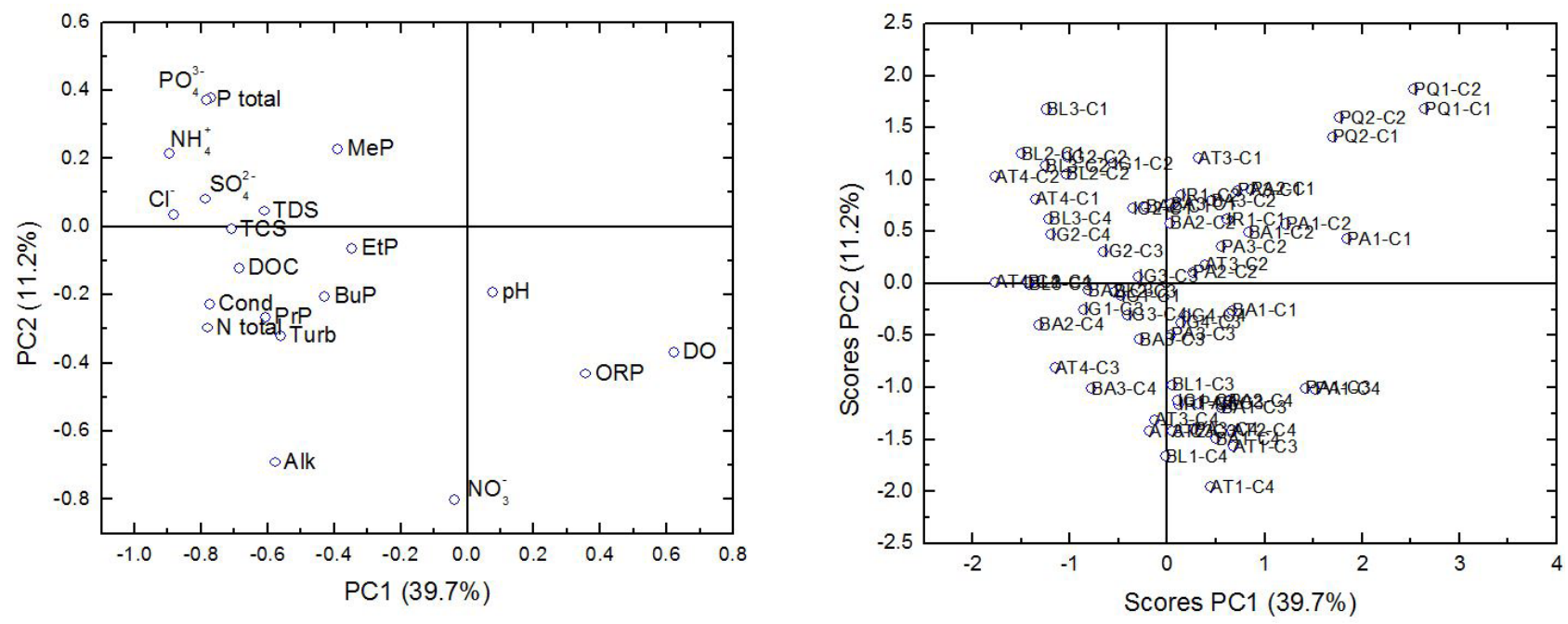

Figure 5. Principal component analysis of the results (PCA) of the parameters analyzed at Atuba (AT), Barigui (BA), Belém (BL), Iguassu (IG), Palmital (PA), Pequeno (PQ), and Iraí (IR) rivers. Parameters: total phosphorus (P total), orthophosphate $\left(\mathrm{PO}_{4}^{3-}\right)$, ammoniacal-N $\left(\mathrm{NH}_{4}^{+} / \mathrm{NH}_{3}\right)$, chloride $(\mathrm{Cl})$, sulfate $\left(\mathrm{SO}_{4}^{2-}\right)$, total dissolved solids (TDS), triclosan (TCS), parabens (MeP, EtP PrP BuP), alkalinity (Alk.) conductivity (Cond.), dissolved organic carbon (DOC), nitrate $\left(\mathrm{NO}_{3}^{-}\right)$, redox potential (ORP), dissolved oxygen (DO), and pH. 
watersheds by domestic effluents, they were grouped on the same side, with vectors indicating correlation between parabens, triclosan and nutrients found in wastewater (chloride ion, orthophosphate and n-ammonia). For the less impacted environments (Palmital and Pequeno Rivers), it has being observed small contamination by emerging compounds, nutrient concentrations and higher dissolved oxygen concentrations (OD).

\section{Risk assessment}

For parabens, due to its lower toxicity (RAMASWAMY et al., 2011) compared with triclosan (which is a bactericide), a RQ greater than unity has not being observed for any of the organisms evaluated, considering both acute and chronic tests (Figures 6 and 7). For most of the monitored sites it has being observed a low risk by the presence of parabens. For IG1 site located at Iguassu River (Metropolitan Region of Curitiba), a moderate risk was observed for the presence of MeP. A similar behavior was also observed for Irai (IR1) and Pequeno (PQ2) rivers. Among the parabens, MeP is the most commonly used compound, followed by $\operatorname{PrP}$ (usually used in association due to synergistic effects).

Even at lower concentrations than MeP, PrP and BuP showed a moderate risk for various sampling sites and diverse organisms. This fact can be explained by the higher toxicity of these compounds compared the toxicity of MeP, which may be associated with increased length of the carbon chain (GONZALEZMARINO et al., 2011).

RQ values for acute tests for parabens ranged from zero (0.0) for environments where parabens were not detected, to 0.126 for $\mathrm{MeP}$ (V. fisheri - bacteria), 0.059 to EtP (Vibrio fisheri - bacteria), 0.024 to $\operatorname{PrP}$ (Daphinia magna - microcrustacean) and 0.029 for BuP (Pimephales promelas - fish).

Risk assessment for the presence of triclosan, considering the acute toxicity, it was observed that for some organisms, especially for low trophic level organisms (algae), the observed triclosan concentrations were higher than the environmentally relevant concentrations (Figures 8 and 9). Therefore, the risk quotientes for these organisms were greater than 1 .

The same pattern was observed in the evaluation performed for the chronic toxicity of this compound (Figure 9). For most organisms evaluated, and also to the environments studied, the risk can be considered moderate $(\mathrm{RQ}>0.01)$. Triclosan concentrations above environmentally relevant concentrations have been observed in other studies, especially for the same trophic levels organisms observed in this study (RAMASWAMY et al., 2011). Due to its sensitivity, algae (P. subcapitata and D. tertiolecta) appears to be the most susceptible organisms to the presence of triclosan in the environment, which can be connected to similarities in the metabolism of algae and bacteria.
MeP

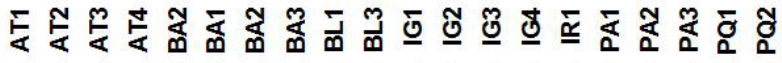

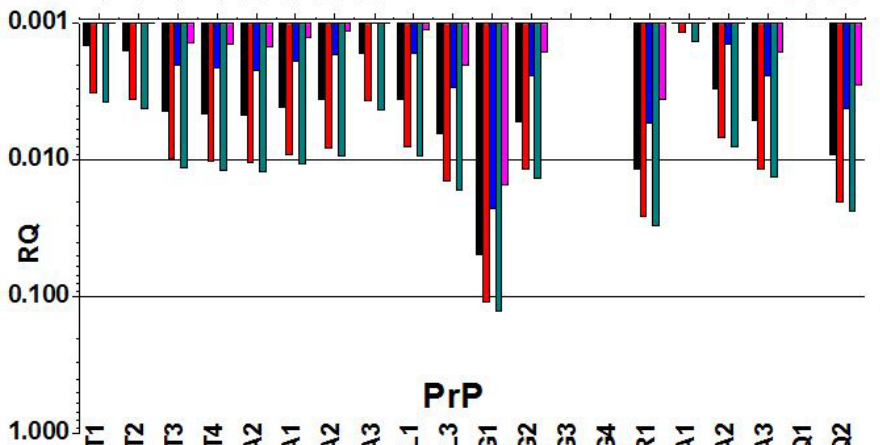

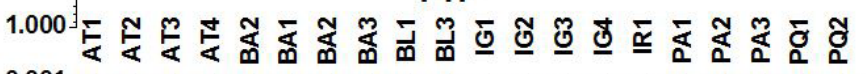

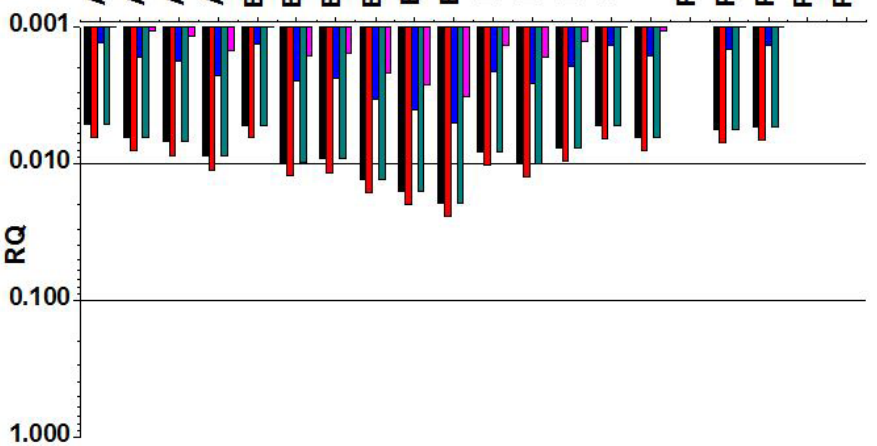

EtP

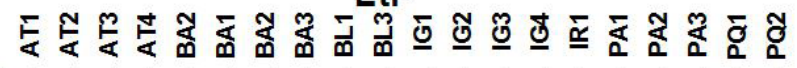
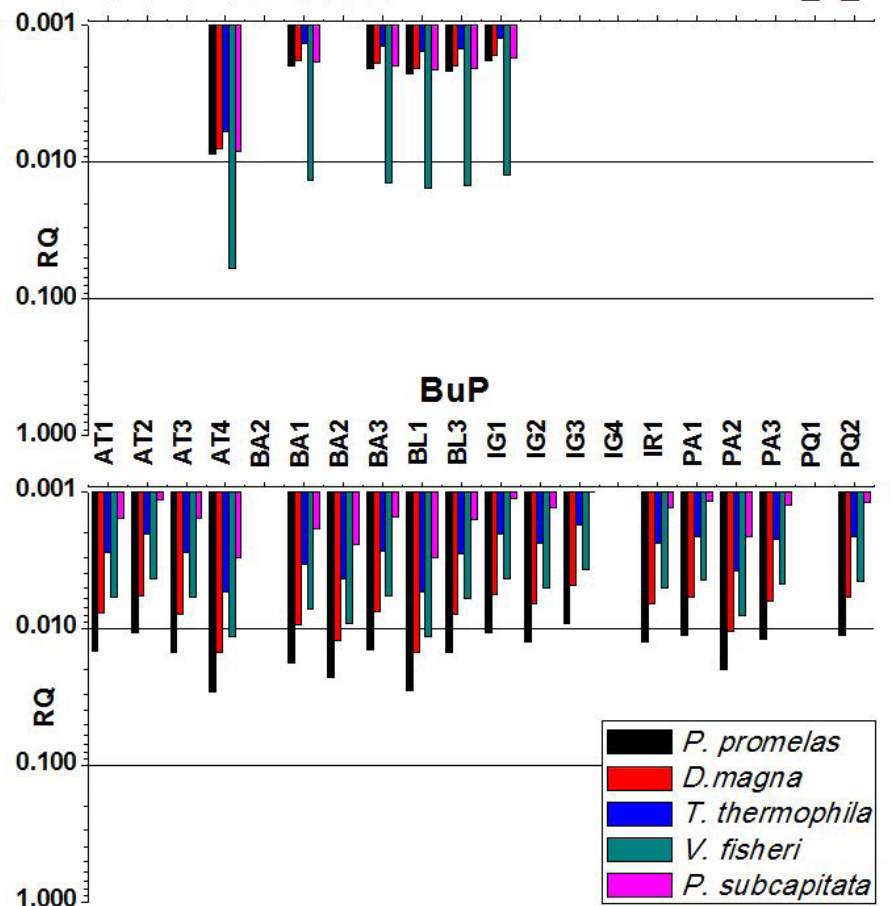

Figure 6. Risk quotients (RQ) for acute toxicity of parabens for different organisms at Upper Iguassu Watershed (MeP - methylparaben, EtP - ethylparaben, PrP - propylparaben, BuP - butylparaben) Atuba (AT), Barigui (BA), Belém (BL), Iguassu (IG), Palmital (PA), Pequeno (PQ), and Iraí (IR) rivers. Sampling period 2011 and 2012. 


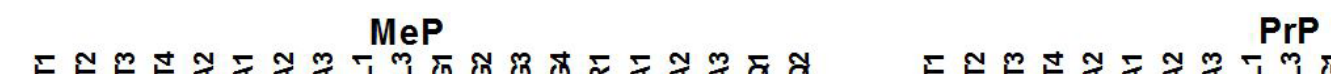

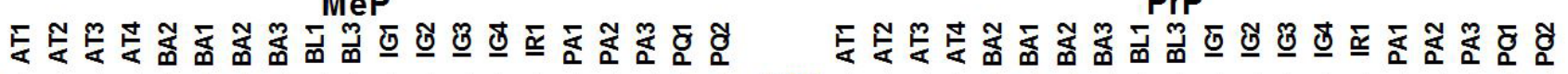
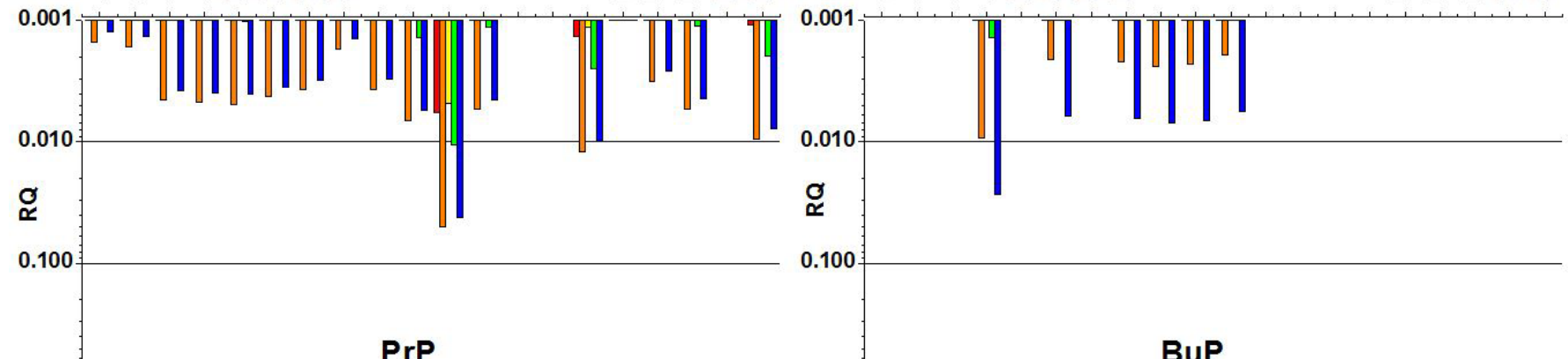

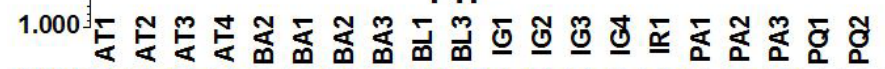
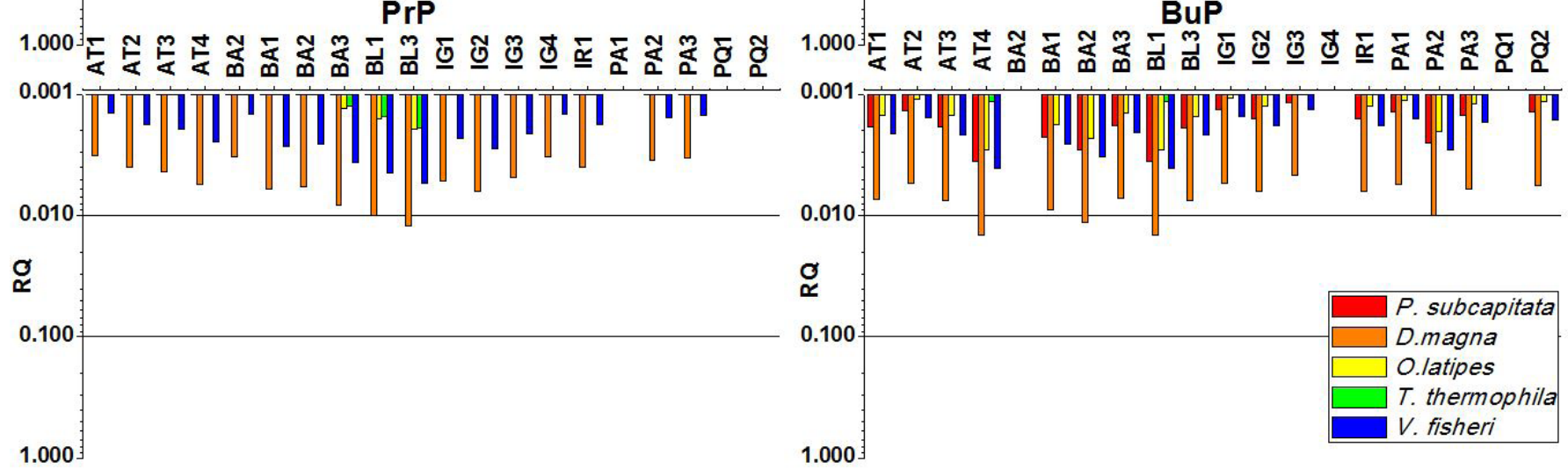

Figure 7. Risk quotients (RQ) for chronic toxicity of parabens for different organisms at Upper Iguassu Watershed (MeP - methylparaben, EtP - ethylparaben, PrP - propylparaben, BuP - butylparaben)). Atuba (AT), Barigui (BA), Belém (BL), Iguassu (IG), Palmital (PA), Pequeno (PQ), and Iraí (IR) rivers. Sampling period 2011 and 2012.

RQ - TCS

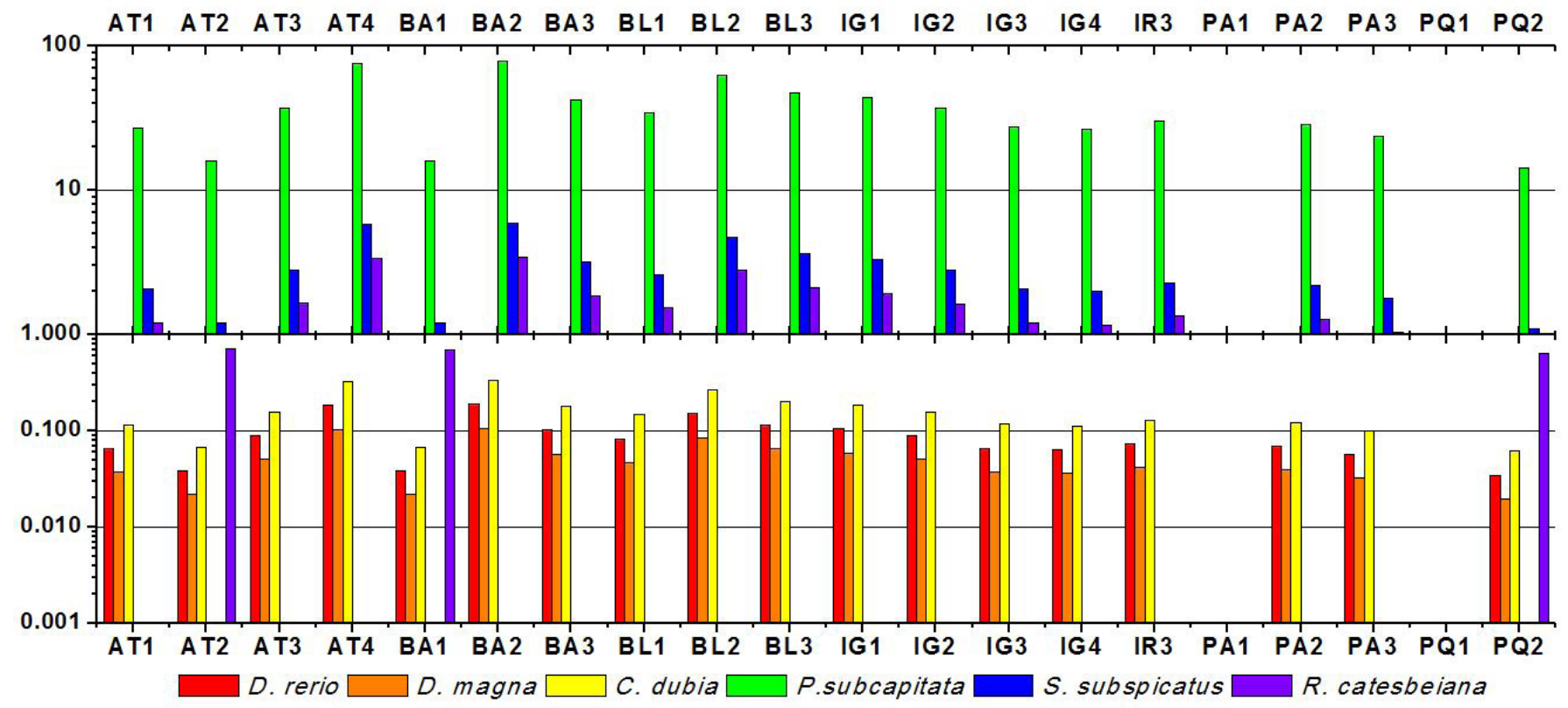

Figure 8. Risk quotients (RQ) for acute toxicity of triclosan (TCS) for different organisms at Upper Iguassu Watershed. Atuba (AT), Barigui (BA), Belém (BL), Iguassu (IG), Palmital (PA), Pequeno(PQ), and Iraí (IR) rivers. Sampling period: 2011 and 2012. 
RQ -TCS

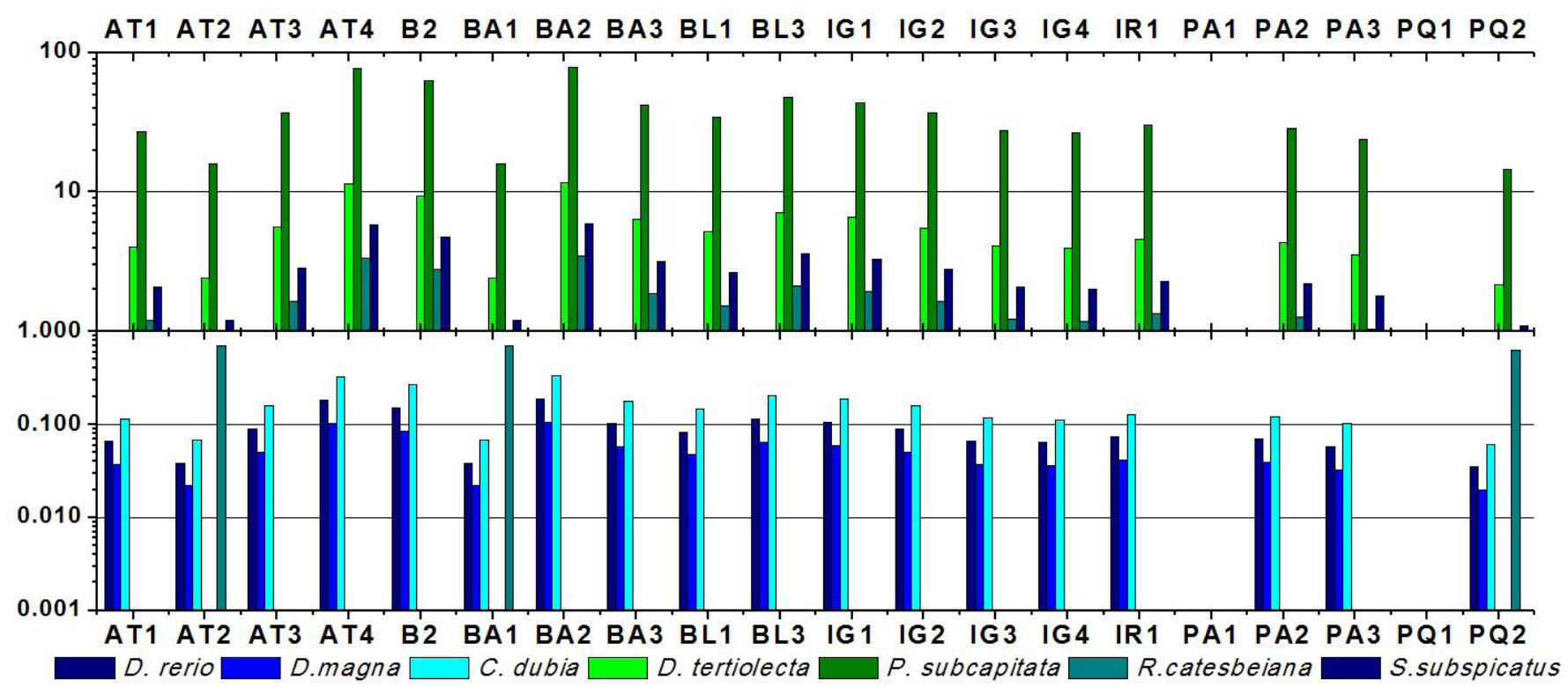

Figure 9. Risk quotients (RQ) for chronic toxicity of triclosan (TCS) for different organisms at Upper Iguassu Watershed. Atuba (AT), Barigui (BA), Belém (BL), Iguassu (IG), Palmital (PA), Pequeno(PQ), and Iraí (IR) rivers. Sampling period: 2011 and 2012.

\section{CONCLUSIONS}

Studies considering compounds such as triclosan and parabens are scarce in most developing countries. In developing countries, the high concentrations of these compounds observed in aquatic environments can be attributed to low levels of sewage collection and treatment and illegal connections. In this study we observed higher concentrations of parabens, especially MeP (2875 $\mathrm{ng} \mathrm{L}^{-1}$ ), an easily degradable compound in wastewater treatment plants, suggesting that these compounds have recently been released into the environment. Higher concentration of triclosan was observed mainly at stations sampled downstream sewage treatment plants, suggesting that these environments are heavily impacted by human activities. Triclosan concentrations suggest that this compound has a high risk for certain groups of organisms. QR values for algae was greater than 1 , indicating that there is an acute and chronic toxicity of triclosan in some sampling sites, mainly in Atuba, Barigui and Belém rivers. Through these results we recommend that collection and treatment of sewage system has to be more efficient, being necessary to eliminate the existing illegal connections. Finally, in addition to these emerging contaminants found in the rivers studied, there may be other compounds that may present a greater risk to biotic community in aquatic environments and should be investigated.

\section{ACKNOWLEDGEMENTS}

The authors would like to thanks the financial support from CNPq (Process 474900/2011-8); SETI/Fundação Araucária (PQ scholarship); CAPES (doctorate scholarship), UTFPR and CT-Infra 2010/FINEP (FNDCT - NIPTA -Núcleo Interdisciplinar de Pesquisa em Tecnologias Ambientais).

\section{REFERENCES}

AL AUKIDY, M.; VERLICCHI, P.; JELIC, A.; PETROVIC, M.; BARCELÒ, D. Monitoring release of pharmaceutical compounds: occurrence and environmental risk assessment of two WWTP effluents and their receiving bodies in the Po Valley, Italy. The Science of the Total Environment, v. 438, p. 15-25, 2012. http://dx.doi. org/10.1016/j.scitotenv.2012.08.061. PMid:22967493.

ALBERO, B.; PÉREZ, R. A.; SÁNCHEZ-BRUNETE, C.; TADEO, J. L. Occurrence and analysis of parabens in municipal sewage sludge from wastewater treatment plants in Madrid (Spain). Journal of Hazardous Materials, v. 239-240, p. 48-55, 2012a. http://dx.doi. org/10.1016/j.jhazmat.2012.05.017. PMid:22640822.

ALBERO, B.; SÁNCHEZ-BRUNETE, C.; MIGUEL, E.; PÉREZ, R. A.; TADEO, J. Determination of selected organic contaminants in soil by pressurized liquid extraction and gas chromatography tandem mass spectrometry with in situ derivatization. Journal of Chromatography. A, v. 1248, p. 9-17, 2012b. http://dx.doi. org/10.1016/j.chroma.2012.05.078. PMid:22683186.

ANDREOLI, C. V.; DALARMI, O.; LARA, A. I.; ANDREOLI, F. N. Os mananciais de abastecimento do sistema integrado da Região Metropolitana de Curitiba - RMC. Revista Técnica da Sanepar, v. 12, n. 12, p. 19-30, 1999.

APHA - AMERICAN PUBLIC HEALTH ASSOCIATION. Standard methods for the examination of water and wastewater. 20th ed. Washington, 1998.

AZZOUZ, A.; RASCÓN, A. J.; BALLESTEROS, E. Simultaneous determination of parabens, alkylphenols, phenylphenols, bisphenol 
A and triclosan in human urine, blood and breast milk by continuous solid-phase extraction and gas chromatography-mass spectrometry. Journal of Pharmaceutical and Biomedical Analysis, v. 119, p. 16-26, 2016. http://dx.doi.org/10.1016/j.jpba.2015.11.024. PMid:26637951.

BENIJTS, T.; LAMBERT, W.; LEENHEER, A. Analysis of multiple endocrine disruptors in environmental waters via wide-spectrum solid-phase extraction and dual-polarity ionization LC-Ion TrapMS/MS. Analytical Chemistry, v. 76, n. 3, p. 704-711, 2004. http:/ / dx.doi.org/10.1021/ac035062x. PMid:14750866.

BESTER, K. Fate of triclosan and triclosan-methyl in sewage treatmentplants and surface waters. Archives of Environmental Contamination and Toxicology, v. 49, n. 1, p. 9-17, 2005. http:/ /dx.doi. org/10.1007/s00244-004-0155-4. PMid:15959704.

BLAIR, B. D.; CRAGO, J. P.; HEDMAN, C. J.; KLAPER, R. D. Pharmaceuticals and personal care products found in the Great Lakes above concentrations of environmental concern. Chemosphere, v. 93, n. 9, p. 2116-2123, 2013. http://dx.doi.org/10.1016/j. chemosphere.2013.07.057. PMid:23973285.

BOBERG, J.; TAXVIG, C.; CHRISTIANSEN, S.; HASS, U. Possible endocrine disrupting effects of parabens and their metabolite. Reproductive Toxicology, v. 30, n. 2, p. 301-312, 2010. http://dx.doi. org/10.1016/j.reprotox.2010.03.011. PMid:20381602.

BRAUSCH, A. J. M.; RAND, G. M. Review of personal care products in the aquatic environment: environmental concentrations and toxicity. Chemosphere, v. 82, n. 11, p. 1518-1532, 2011. http:// dx.doi.org/10.1016/j.chemosphere.2010.11.018. PMid:21185057.

BYFORD, J. R.; SHAW, L. E.; DREW, M. G.; POPE, G. S.; SAUER, M. J.; DARBRE, P. D. Oestrogenic activity of parabens in MCF7 human breast cancer cells. The Journal of Steroid Biochemistry and Molecular Biology, v. 80, n. 1, p. 49-60, 2002. http://dx.doi. org/10.1016/S0960-0760(01)00174-1. PMid:11867263.

CANOSA, P.; RODRIGUEZ, I.; RUBI, E.; BOLLAIN, M. H.; CELA, R. Optimisation of a solid-phase microextraction method for the determination of parabens in water samples at the lowng per litre level. Journal of Chromatography A, v. 1124, n. 1-2, p. 3-10, 2006. http://dx.doi.org/10.1016/j.chroma.2006.03.045. PMid:16600260.

CHAU, W. C.; WU, J.; CAI, Z. Investigation of levels and fate of triclosan in environmental waters from the analysis of gas chromatography coupled with ion trap mass spectrometry. Chemosphere, v. 73, n. 1, p. S13-S17, 2008. Suplemento http:// dx.doi.org/10.1016/j.chemosphere.2007.01.087. PMid:18440583.

CHRISTENSEN, A. M.; MARKUSSEN, B.; BAUN, A.; HALLING-SORENSEN, B. Probabilistic environmental risk characterization of pharmaceuticals in sewage treatment plant discharges. Chemosphere, v. 77, n. 3, p. 351-358, 2009. http:// dx.doi.org/10.1016/j.chemosphere.2009.07.018. PMid:19682723.

COOGAN, M. A.; EDZIYIE, R. E.; LA POINT, T. W.; VENABLES, B. J. Algal bioaccumulation of triclocarban, triclosan, and methyl- triclosan in a North Texas wastewater treatment plant receiving stream. Chemosphere, v. 67, n. 10, p. 1911-1918, 2007. http://dx.doi. org/10.1016/j.chemosphere.2006.12.027. PMid:17275881.

FAIR, P. A.; LEE, H. B.; ADAMS, J.; DARLING, C.; PACEPAVICIUS, G.; ALAEE, M.; BOSSART, G. D.; HENRY, N.; MUIR, D. Occurrence of triclosan in plasma of wild Atlantic bottlenose dolphins (Tursiops truncatus) and in their environment. Environmental Pollution, v. 157, n. 8-9, p. 2248-2254, 2009. http:// dx.doi.org/10.1016/j.envpol.2009.04.002. PMid:19410343.

FERREIRA, A. M. C.; MÖDER, M.; LAESPADA, M. E. F. Stir bar sorptive extraction of parabens, triclosan and methyl triclosan from soil, sediment and sludge with in situ derivatization and determination by gas chromatography-mass spectrometry. Journal of Chromatography A, v. 1218, n. 25, p. 3837-3844, 2011. http:// dx.doi.org/10.1016/j.chroma.2011.04.055. PMid:21571279.

FRANZ, S.; ALTENBURGER, R.; HEILMEIER, H.; SCHMITTJANSEN, M. What contributes to the sensitivity of microalgae to triclosan? Aquatic Toxicology, v. 90, n. 2, p. $102-$ 108, 2008. http://dx.doi.org/10.1016/j.aquatox.2008.08.003. PMid:18824267.

GASPERI, J.; GEARA, D.; LORGEOUX, C.; BRESSY, A.; ZEDEK, S.; ROCHER, V.; EL SAMRANI, A.; CHEBBO, G.; MOILLERON, R. First assessment of triclosan, triclocarban and paraben mass loads at a very large regional scale: case of Paris conurbation (France). The Science of the Total Environment, v. 493, p. 854-861, 2014. http://dx.doi.org/10.1016/j.scitotenv.2014.06.079. PMid:25000581.

GONZALEZ-MARINO, I.; QUINTANA, J.; RODRÍGUEZ, I.; SCHRADER, S.; MOEDER, M. Fully automated determination of parabens, triclosan and methyl triclosan in wastewater by microextraction by packed sorbents and gas chromatography-mass spectrometry. Analytica Chimica Acta, v. 684, n. 1, p. 59-66, 2011. http://dx.doi.org/10.1016/j.aca.2010.10.049.

GORGA, M.; PETROVIC, M.; BARCELO, D. Multi-residue analytical method for the determination of endocrine disruptors and related compounds in river and waste water using dual column liquid chromatography switching system coupled to mass spectrometry. Journal of Chromatography A, v. 1295, p. 57-66, 2013. http://dx.doi.org/10.1016/j.chroma.2013.04.028. PMid:23683400.

HALDEN, R. U.; PAULL, D. H. Co-occurrence of triclocarban and triclosan in US water resources. Environmental Science \& Technology, v. 39, n. 6, p. 1420-1426, 2005. http://dx.doi.org/10.1021/ es049071e. PMid:15819193.

HEIDLER, J.; HALDEN, R. U. Mass balance assessment of triclosan removal during conventional sewage treatment. Chemosphere, v. 66, n. 2, p. 362-369, 2007. http://dx.doi.org/10.1016/j. chemosphere.2006.04.066. PMid:16766013.

HUA, W.; BENNETT, E. R.; LETCHER, R. J. Triclosan in waste and surface waters from the upper Detroit River by liquid 
chromatography-electrospray-tandem quadrupole mass spectrometry. Environment International, v. 31, n. 5, p. 621-630, 2005. http://dx.doi. org/10.1016/j.envint.2004.10.019. PMid:15910958.

IDE, A. H.; CARDOSO, F. D.; SANTOS, M. M.; KRAMER, R. D.; MIZUKAWA, A.; AZEVEDO, J. C. R. Cafeína como indicador de contaminação por esgotos domésticos na Bacia do Alto Iguaçu. Revista Brasileira de Recursos Hídricos, v. 18, n. 2, p. 201-211, 2013. http://dx.doi.org/10.21168/rbrh.v18n2.p201-211.

JONKERS, N.; KOHLER, H. E.; DAMMSHAUSER, A.; GIGER, W. Mass flows of endocrine disruptors in the Glatt River during varying weather conditions. Environmental Pollution, v. 157, n. 3, p. 714-723, 2009. http://dx.doi.org/10.1016/j.envpol.2008.11.029. PMid:19117654.

KANTIANI, F.; ASPERGER, D.; RUBIO, F.; GONZALEZ, S.; ALDA, M. J. L.; PETROVIC, M.; SHELVER, W. L.; BARCELO, D. Triclosan and methyl-triclosan monitoring study in the northeast of Spain using a magnetic particle enzyme immunoassay and confirmatory analysis by gas chromatography-mass spectrometry. Journal of Hydrology, v. 361, n. 1, p. 1-9, 2008. http://dx.doi. org/10.1016/j.jhydrol.2008.07.016.

KASPRZYK-HORDERN, B.; DINSDALE, R. M.; GUWY, A. J. The removal of pharmaceuticals, personal care products, endocrine disruptors and illicit drugs during wastewater treatment and its impact on the quality of receiving waters. Water Research, v. 43, n. 2, p. 363-380, 2009. http://dx.doi.org/10.1016/j.watres.2008.10.047. PMid:19022470.

KATZ, D. R.; CANTWELL, M. G.; SULLIVAN, J. C.; PERRON, M. M.; BURGESS, R. M.; HO, K. T.; CHARPENTIER, M. A. Factors regulating the accumulation and spatial distribution of the emerging contaminant triclosan in the sediments of an urbanized estuary: Greenwich Bay, Rhode Island, USA. The Science of the Total Environment, v. 443, p. 123-133, 2013. http://dx.doi.org/10.1016/j. scitotenv.2012.10.052. PMid:23183224.

KOLPIN, D. W.; FURLONG, E. T.; MEYER, M. T.; THURMAN, E. M.; ZAUGG, S. D.; BARBER, L. B.; BUXTON, H. T. Pharmaceuticals, hormones, and other organic wastewater contaminants in U.S. streams, 1999-2000: a national reconnaissance. Environmental Science \& Technology, v. 36, n. 6, p. 1202-1211, 2002. http://dx.doi.org/10.1021/es011055j. PMid:11944670.

KOSMA, C. I.; LAMBROPOULOU, D. A.; ALBANIS, T. A. Investigation of PPCPs in wastewater treatment plants in Greece: Occurrence, removal and environmental risk assessment. The Science of the Total Environment, v. 466-467, p. 421-438, 2014. http://dx.doi. org/10.1016/j.scitotenv.2013.07.044. PMid:23933429.

KRAMER, R. D.; MIZUKAWA, A.; IDE, A. H.; MARCANTE, L. O.; SANTOS, M. M.; AZEVEDO, J. C. R. Determinação de anti-inflamatórios na água e sedimento e suas relações com a qualidade da água na bacia do Alto Iguaçu, Curitiba-PR. Revista Brasileira de Recursos Hídricos, v. 20, n. 3, p. 657-667, 2015. http:// dx.doi.org/10.21168/rbrh.v20n3.p657-667.
LARSSON, K.; LJUNG BJÖRKLUND, K.; PALM, B.; WENNBERG, M.; KAJ, L.; LINDH, C. H.; JÖNSSON, B. A. G.; BERGLUND, M. Exposure determinants of phthalates, parabens, bisphenol A and triclosan in Swedish mothers and their children. Environment International, v. 73, p. 323-333, 2014. http://dx.doi.org/10.1016/j. envint.2014.08.014. PMid:25216151.

LEE, H.; PEART, T. E. M.; SVOBODA, M. L. Determination of endocrine-disrupting phenols, acidic pharmaceuticals and personal-care products in sewage by solid-phase extraction and gas chromatography-mass spectrometry. Journal of Chromatography. A, v. 1094, n. 1, p. 122-129, 2005. http://dx.doi.org/10.1016/j. chroma.2005.07.070. PMid:16257298.

LINDSTROM, A.; BUERGE, I. J.; POIGER, T.; BERGQVIST, P. A.; MULLER, M. D.; BUSER, H. R. Occurrence and environmental behavior of the bactericide triclosan and its methyl derivative in surface waters and in wastewater. Environmental Science \& Technology, v. 36, n. 11, p. 2322-2329, 2002. http://dx.doi.org/10.1021/ es0114254. PMid:12075785.

LOOS, R.; WOLlGAST, J.; HUBER, T.; HANKE, G. Polar herbicides, pharmaceutical products, perfluorooctanesulfonate (PFOS), perfluorooctanoate (PFOA), and nonylphenol and its carboxylates and ethoxylates in surface and tap waters around Lake Maggiore in Northern Italy. Analytical and Bioanalytical Chemistry, v. 387, n. 4, p. 1469-1478, 2007. http:/ /dx.doi.org/10.1007/s00216006-1036-7. PMid:17200857.

LOPEZ-AVILA, V.; HITES, R. A. Organic compounds in an industrial wastewater: their transport into sediments. Environmental Science \& Technology, v. 14, n. 11, p. 1382-1390, 1980. http://dx.doi. org/10.1021/es60171a007.

LU, S.; ARCHER, M. Fatty acid synthesis is a potential target for the chemoprevention of breast cancer. Carcinogenesis, v. 26, n. 1, p. 153-157, 2005. http://dx.doi.org/10.1093/carcin/bgh278. PMid:15358634.

LUNDOV, M. D.; MOESBY, L.; ZACHARIAE, C.; JOHANSEN, J. D. Contamination versus preservation of cosmetics: a review on legislation, usage, infections, and contact allergy. Contact Dermatitis, v. 60 , n. 2, p. 70-78, 2009. http://dx.doi.org/10.1111/j.16000536.2008.01501.x. PMid:19207376.

MCAVOY, D. C.; SCHATOWITZ, B.; JACOB, M.; HAUK, A.; ECKHOFF, W. S. Measurement of triclosan in wastewater treatment systems. Environmental Toxicology and Chemistry, v. 21, n. 7, p. 1323-1329, 2002. http://dx.doi.org/10.1002/etc.5620210701. PMid:12109730.

MEYER, B. K.; NI, A.; HU, B.; SHI, L. Antimicrobial preservative use in parenteral products: past and present. Journal of Pharmaceutical Sciences, v. 96, n. 12, p. 3155-3167, 2007. http://dx.doi.org/10.1002/ jps.20976. PMid:17722087.

MONTES, R. I.; RODRÍGUEZ, I.; RUBÍ, E.; CELA, R. Dispersive liquid-liquid microextraction applied to the simultaneous 
derivatization and concentration of triclosan and methyltriclosan in water samples. Journal of Chromatography A, v. 1216, n. 2, p. 205-210, 2009. http://dx.doi.org/10.1016/j.chroma.2008.11.068. PMid:19084234.

MORRALL, D.; MCAVOY, D.; SCHATOWITZ, B.; INAUEN, J.; JACOB, M.; HAUK, A.; ECKHOFF, W. A field study of triclosan loss rates in river water. Chemosphere, v. 54, n. 5, p. 653660, 2004. http://dx.doi.org/10.1016/j.chemosphere.2003.08.002. PMid:14599511.

NEWTON, P.; CADENA, S.; ROCHA, M.; CARNIERI, E.; OLIVEIRA, M. Effect of triclosan (TRN) on energy-linked functions of rat liver mitochondria. Toxicology Letters, v. 160, n. 1, p. 49-59, 2005. http://dx.doi.org/10.1016/j.toxlet.2005.06.004. PMid:16023799.

OKUMURA, T.; NISHIKAWA, Y. Gas chromatography-mass spectrometry determination of triclosans in water, sediment and fish samples via methylation with diazomethane. Analytica Chimica Acta, v. 325, n. 3, p. 175-184, 1996. http:/ / dx.doi.org/10.1016/00032670(96)00027-X.

OSAWA, R. A.; IDE, A. H.; SAMPAIO, N. M. F. M.; AZEVEDO, J. C. R. Determinação de fármacos anti-hipertensivos em águas superficiais na região metropolitana de Curitiba. Revista Brasileira de Recursos Hidricos, v. 20, n. 4, p. 1039-1050, 2015. http://dx.doi. org/10.21168/rbrh.v20n4.p1039-1050.

PECK, A. M. Analytical methods for the determination of persistent ingredientsof personal care products in environmental matrices. Analytical and Bioanalytical Chemistry, v. 386, n. 4, p. 907-939, 2006. http://dx.doi.org/10.1007/s00216-006-0728-3. PMid:17047946.

PEDROUZO, M.; BORRULL, F.; MARCÉ, R. M.; POCURULL, E. Ultra-high-performance liquid chromatography-tandem mass spectrometry for determining the presence of eleven personal care products in surface and wastewaters. Journal of Chromatography. A, v. 1216, n. 42, p. 6994-7000, 2009. http://dx.doi.org/10.1016/j. chroma.2009.08.039. PMid:19747689.

PENG, X.; YU, Y.; TANG, C.; TAN, J.; HUANG, Q.; WANG, Z. Occurrence of steroid estrogens, endocrine-disrupting phenols, and acid pharmaceutical residues in urban riverine water of the Pearl River Delta, South China. The Science of the Total Environment, v. 397, n. 1-3, p. 158-166, 2008. http://dx.doi.org/10.1016/j. scitotenv.2008.02.059. PMid:18407320.

RAMASWAMY, B. J.; SHANMUGAM, G.; VELU, G.; RENGARAJAN, B.; LARSSON, D. G. J. GC-MS analysis and ecotoxicological risk assessment of triclosan, carbamazepine and parabens in Indian rivers. Journal of Hazardous Materials, v. 186, n. 2-3, p. 1586-1593, 2011. http://dx.doi.org/10.1016/j. jhazmat.2010.12.037. PMid:21216531.

REGUEIRO, J.; LLOMPARTA, M.; PSILLAKIS, E.; GARCIAMONTEAGUDO, J. C.; GARCIA-JARES, C. Ultrasound-assisted emulsification-microextraction of phenolic preservatives in water.
Talanta, v. 79, n. 5, p. 1387-1397, 2009. http://dx.doi.org/10.1016/j. talanta.2009.06.015. PMid:19635375.

ROUTLEDGE, E. J.; PARKER, J.; ODUM, J.; ASHBY, J.; SUMPTER, J. P. Some alkyl hydroxyl benzoate preservatives (parabens) are estrogenic. Toxicology and Applied Pharmacology, v. 153, n. 1, p. 12-19, 1998. http://dx.doi.org/10.1006/taap.1998.8544. PMid:9875295.

SABALIUNAS, D.; WEBB, S. F; HAUK, A.; JACOB, M.; ECKHOFF, W. S. Environmental fate of Triclosan in the River Aire Basin, UK. Water Research, v. 37, n. 13, p. 3145-3154, 2003. http://dx.doi. org/10.1016/S0043-1354(03)00164-7. PMid:14509701.

SCHWEIZER, H. P. Triclosan: a widely used biocide and its link to antibiotics FEMS. Microbiology Letters, v. 202, n. 1, p. 1-7, 2001. http://dx.doi.org/10.1111/j.1574-6968.2001.tb10772.x. PMid:11506900.

SINGER, H.; MÜLLER, S.; TIXIER, C.; PILLONEL, L. Triclosan: occurrence and fate of a widely used biocide in the aquatic environment: field measurements in wastewater treatment plants, surface waters, and lake sediments. Environmental Science \& Technology, v. 36, n. 23, p. 4998-5004, 2002. http://dx.doi. org/10.1021/es025750i. PMid:12523412.

SONI, M. G.; CARABIN, I. G.; BURDOCK, G. A. Safety assessment of esters of p-hydroxybenzoic acid (parabens). Food and Chemical Toxicology, v. 43, n. 7, p. 985-1015, 2005. http://dx.doi. org/10.1016/j.fct.2005.01.020. PMid:15833376.

SPANIER, A. J.; FAUSNIGHT, T.; CAMACHO, T. F.; BRAUN, J. $\mathrm{M}$. The associations of triclosan and paraben exposure with allergen sensitization and wheeze in children. Allergy Asthma, v. 35, n. 6, p. 475-481, 2014. http://dx.doi.org/10.2500/aap.2014.35.3803. PMid:25584915.

SPONGBERG, A. L.; WITTER, J. D.; ACUNA, J.; VARGAS, J.; MURILlO, M.; UMANA, G.; GOMEZ, E.; PEREZ, G. Reconnaissance of selected PPCP compounds in Costa Rican surface waters. Water Research, v. 45, n. 20, p. 6709-6717, 2011. http://dx.doi.org/10.1016/j.watres.2011.10.004. PMid:22048020.

TEWARI, S.; JINDAL, R.; KHO, Y. L.; EO, S.; CHOI, K. Major pharmaceutical residues in wastewater treatment plants and receiving waters in Bangkok, Thailand, and associated ecological risks. Chemosphere, v. 91, n. 5, p. 697-704, 2013. http://dx.doi. org/10.1016/j.chemosphere.2012.12.042. PMid:23332673.

VALCARCEL, Y.; ALONSO, S. G.; RODRIGUEZ-GIL, J. L.; GIL, A.; CATALA, M. Detection of pharmaceutically active compounds in the rivers and tap water of the Madrid Region (Spain) and potential ecotoxicological risk. Chemosphere, v. 84, n. 10, p. 13361348, 2011. http://dx.doi.org/10.1016/j.chemosphere.2011.05.014. PMid:21641628.

VERLICCHI, P.; AL AUKIDY, M.; ZAMBELLO, E. Occurrence of pharmaceutical compounds in urban wastewater: Removal, 
mass load and environmental risk after a secondary treatment-a review. The Science of the Total Environment, v. 429, p. 123-155, 2012. http://dx.doi.org/10.1016/j.scitotenv.2012.04.028. PMid:22583809.

VILLAVERDE-DE-SÁA, E.; GONZÁLEZ-MARIÑO, I.; QUINTANA, J. B.; RODIL, R.; RODRÍGUEZ, I.; CELA, R. Insample acetylation-non-porous membrane-assisted liquid-liquid extraction for the determination of parabens and triclosan in water samples. Analytical and Bioanalytical Chemistry, v. 397, n. 6, p. 2559-2568, 2010. http://dx.doi.org/10.1007/s00216-010-3789-2. PMid:20473484.

WILSON, B.; CHEN, R. F.; CANTWELL, M.; GONTZ, A.; ZHU, J.; OLSEN, C. R. The partitioning of triclosan between aqueous and particulate bound phases in the Hudson River Estuary. Marine Pollution Bulletin, v. 59, n. 4, p. 207-212, 2009. http:/ /dx.doi. org/10.1016/j.marpolbul.2009.03.026. PMid:19559448.

WIND, T.; WERNER, U.; JACOB, M.; HAUK, A. Environmental concentrations of boron, LAS, EDTA, NTA and Triclosan simulated with GREAT-ER in the river Itter. Chemosphere, v. 54, n. 8, p. 1145 1154, 2004. http://dx.doi.org/10.1016/j.chemosphere.2003.09.036. PMid:14664842.

WU, J. L.; LAM, N. P.; MARTENS, D.; KETTRUP, A.; CAI, Z. Triclosan determination in water related to wastewater treatment. Talanta, v. 72, n. 5, p. 1650-1654, 2007. http://dx.doi.org/10.1016/j. talanta.2007.03.024. PMid:19071811.

XIE, Z.; EBINGHAUS, R.; FLÖSER, G.; CABA, A.; RUCK, W. Occurrence and distribution of triclosan in the German Bight (North Sea). Environmental Pollution, v. 156, n. 3, p. 1190-1195, 2008. http://dx.doi.org/10.1016/j.envpol.2008.04.008. PMid:18490092.

YAMAMOTO, H.; TAMURA, I.; HIRATA, Y.; KATO, J.; KAGOTA, K.; KATSUKI, S.; YAMAMOTO, A.; KAGAMI, Y.; TATARAZAKO, N. Aquatic toxicity and ecological risk assessment of seven parabens: Individual and additive approach. The Science of the Total Environment, v. 410-411, p. 102-111, 2011. http://dx.doi. org/10.1016/j.scitotenv.2011.09.040. PMid:22051549.
YING, G. G.; KOOKANA, R. S. Triclosan in wastewaters and biosolids from Australian wastewater treatment plants. Environment International, v. 33, n. 2, p. 199-205, 2007. http://dx.doi.org/10.1016/j. envint.2006.09.008. PMid:17055058.

YU, Y.; WU, L.; CHANG, A. Seasonal variation of endocrine disrupting compounds, pharmaceuticals and personal care products in wastewater treatment plants. The Science of the Total Environment, v. 442, p. 310-316, 2013. http://dx.doi.org/10.1016/j. scitotenv.2012.10.001. PMid:23178835.

ZHANG, B. H.; GUO, Y. L.; JIN, Y.; YIN, Z. J.; ZHU, Q. Study of the application of triclosan in antibacterial finishing of cotton fabric. Progress in Textile Science \& Technology, v. 1, p. 3, 2007.

ZHAO, J. L.; ZHANG, Q. Q.; CHEN, F.; WANG, L.; YING, G. G.; LIU, Y. S.; YANG, B.; ZHOU, L. J.; LIU, S.; SU, H. C.; ZHANG, R. Q. Evaluation of triclosan and triclocarban at river basin scale using monitoring and modeling tools: implications for controlling of urban domestic sewage discharge. Water Research, v. 47, n. 1, p. 395-405, 2013. http://dx.doi.org/10.1016/j.watres.2012.10.022. PMid:23127624.

\section{Authors contributions}

Mauricius Marques dos Santos: contributed for the analytical method development and validation.

Franciane de Almeida Brehm: contributed during field preparation and sampling and laboratory analysis procedure.

Tais Cristina Filippe: contributed during field preparation and sampling and laboratory analysis procedure.

Heloise Garcia Knapik: contributed for paper review and translation.

Júlio César Rodrigues de Azevedo: Project coordinator, contributed during field sampling and results analysis and discussion. 